\title{
Effect of Three Years' Application of Biogas Digestate and Mineral Waste to Soil on Phytochemical Quality of Rapeseed
}

\author{
Krzysztof Różyło $^{1 *}$, Sylwia Andruszczak ${ }^{1}$, Ewa Kwiecińska-Poppe ${ }^{1}$, \\ Renata Różyło ${ }^{2}$, Piotr Kraska ${ }^{1}$ \\ ${ }^{1}$ Department of Herbology and Plant Cultivation Techniques \\ ${ }^{2}$ Department of Food Engineering and Machines, \\ University of Life Sciences in Lublin, Lublin, Poland
}

Received: 26 October 2017

Accepted: 5 February 2018

\begin{abstract}
Using waste for plant fertilization requires identifying and reducing any possible undesired effects. The aim of this study was to investigate the effect of fertilization with biogas residue (BD) and mining waste (carboniferous mudstone and clay rock from a coal mine - MS) on oilseed rape (OSR) health quality of seeds in relation to conventional fertilization (NPK) and no fertilization. In the first and second years of the study the highest seed and fat yield was obtained from the NPK treatment. However, in the third year the highest yield was found using MS+BD. The lowest glucosinolate content was determined in OSR seeds fertilized with MS in the second year. The ratio of omega-6/omega-3 FA varied in a narrow range from 2.15 (NPK and MS) to 2.21 (BD and MS+BD). The most preferred form of fertilization in reducing heavy metal bioaccumulation (BAI) in seeds was MS+BD and NPK. NPK fertilization primarily reduced $\mathrm{BAI}$ of $\mathrm{Zn}, \mathrm{B}, \mathrm{Mn}, \mathrm{Cd}, \mathrm{Co}$, and $\mathrm{Fe}$, whereas $\mathrm{MS}+\mathrm{BD}$ reduced $\mathrm{BAI}$ of $\mathrm{Cu}, \mathrm{Sr}, \mathrm{Cr}, \mathrm{Ba}$, and $\mathrm{Pb}$. Results suggest that the wastes evaluated can be an interesting alternative for conventional fertilization in tested soil without the risk of a significant decrease in OSR quality.
\end{abstract}

Keywords: waste recycling, heavy metals, fatty acids, glucosinolate, clay rocks

\section{Introduction}

Environmental protection problems and efforts to increase agricultural productivity have resulted in attempts to use various mineral and organic wastes to fertilize plants and to improve soil properties [1-2]. The residues produced in methanogenesis in a biogas

*e-mail: krzysztof.rozylo@up.lublin.pl plant (biogas residue (BD), biogas digestate, biogas waste) are a relatively well-known material used for fertilization. The research on $\mathrm{BD}$ reveals that this waste improves soil physical and chemical properties, increases the organic carbon content, increases plant yield, and decreases the nitrate content in plants compared to mineral fertilization [3-5]. BD contains more ammonium nitrogen $\left(\mathrm{NH}_{4+} / \mathrm{NH}_{3+}\right)$ than other types of organic biomass [6-8]. Depending on feedstocks used for biogas production, BD can significantly differ in the content and 
proportions of macro- and micronutrients [8-9]. A study conducted by Różyło et al. [10] shows that BD contains a disproportionately large amount of $\mathrm{K}\left(2.69 \mathrm{~g} \mathrm{~kg}^{-1} \mathrm{DM}\right)$ and $\mathrm{Na}\left(0.29 \mathrm{~g} \mathrm{~kg}^{-1} \mathrm{DM}\right)$ in relation to other elements.

Also, mining waste (MS) in the form of clay minerals has great potential to increase the agronomic efficiency of light soils. Mudstones and claystones, which constitute the major part of waste, exhibit high capabilities of organic and inorganic compound sorption. The sorption efficacy of claystones in relation to organic compounds may amount to up to $50 \%$ [11-12]. Thanks to these characters, MS can be used as stabilizers of fertilizer compound transformations in the soil and decrease the effect of leaching them out of the soil.

The modifications aimed at increasing production efficiency often cause negative changes of the obtained rapeseed oil properties. Studies conducted over the last several decades show that fertilization plays a huge role in the quality of plant production, modeling quantitative and qualitative changes in seed composition [13-16].

The change in the chemical composition and physical properties of soil after the incorporation of waste materials may disturb the ion balance of the soil and alter the properties of plants in an unpredictable way. In response to changing environmental conditions and adapting to existing conditions, plants modify their metabolism, and therefore the composition and quality of food of plant origins also changes [17-18]. While using waste materials for plant fertilization, it is important to identify and exclude or reduce any possible undesired effects. In the agronomic evaluation of the usability of waste, chemical analyses (chemical properties and the presence of organic and inorganic contaminants) as well as ecotoxicological evaluations are used [10, 19]. Nevertheless, such research does not answer the question concerning biochemical changes in plants.

Following palm and soybean oil, rapeseed oil is one of three most popular plant oil sources in the world. The majority of rapeseed oil is used by the food industry for direct or indirect consumption. Lipids are considered one of the most elemental nutrients for humans. The importance of food fats for the human organism indirectly stems from the fact that they provide highenergy respiratory substrates and essential fat-soluble vitamins (A, D, E, K). Lipid metabolism generates many bioactive lipid molecules, which are fundamental mediators of multiple signaling pathways, and they are also indispensable compounds of cell membranes. Lipids participate in lipoprotein metabolism, which is divided into two pathways: exogenous lipids and endogenous lipids. Lipids consist of fatty acids (FA), classified mostly according to the presence or absence of double bonds as saturated (SFA - without double bonds), monounsaturated (MUFA - with one double bond) and polyunsaturated fatty acids (PUFA - with two or up to six double bonds); further, as cis or trans based on the configuration of the double bonds and as n3 or n6 PUFA depending on the position of the first double bond from the fatty acid methyl-end. Exogenous FA for the human
Table 1. Chemical properties of control soil (podzolic soilPS), biogas residue (BD), and mining waste (MS) determined immediately before the start of the field experiment [9] (mean, $\mathrm{n}=3)$.

\begin{tabular}{|c|c|c|c|}
\hline Parameter & PS & $\mathrm{BD}$ & MS \\
\hline $\begin{array}{l}\text { dry matter } \\
(\%)\end{array}$ & - & $8-9$ & $75-80$ \\
\hline $\begin{array}{c}\mathrm{pH}(\text { in } 1 \mathrm{M} \\
\mathrm{KCl})\end{array}$ & 4.4 & 9.9 & 7.8 \\
\hline $\mathrm{C} / \mathrm{N}$ & 23.8 & 22.0 & 77.4 \\
\hline $\mathrm{EC}(\mathrm{mS} / \mathrm{cm})$ & 1.20 & 3.70 & 0.84 \\
\hline Element & \multicolumn{3}{|c|}{$\mathrm{mg} \mathrm{kg}^{-1} \mathrm{DW}$} \\
\hline TOC & 9506 & 633027 & 281195 \\
\hline $\mathrm{TN}$ & 413.7 & 28820 & 3631 \\
\hline $\mathrm{P}$ & 49.4 & 5580.6 & 14.8 \\
\hline K & 45.1 & 26907 & 333.8 \\
\hline $\mathrm{Mg}$ & 10.7 & 4420.4 & 139.8 \\
\hline $\mathrm{Fe}$ & 393.6 & 1445.4 & 4200.8 \\
\hline $\mathrm{Ca}$ & 222.0 & 311.6 & 761.0 \\
\hline $\mathrm{Na}$ & 603.3 & 2900.2 & 1450.3 \\
\hline $\mathrm{S}-\mathrm{SO}_{4}$ & 7.8 & 225.1 & 132.7 \\
\hline $\mathrm{B}$ & 0.5 & 23.4 & 10.1 \\
\hline $\mathrm{Mn}$ & 61.4 & 246.1 & 96.6 \\
\hline $\mathrm{Cu}$ & 0.5 & 14.2 & 14.6 \\
\hline $\mathrm{Zn}$ & 2.5 & 145.1 & 24.4 \\
\hline $\mathrm{Al}$ & 4505.1 & 512.7 & 20870.1 \\
\hline $\mathrm{Cr}$ & 10.45 & $<0.1$ & 19.8 \\
\hline $\mathrm{Pb}$ & 10.26 & $<0.1$ & 13.7 \\
\hline $\mathrm{Ni}$ & 11.55 & $<0.1$ & 4.51 \\
\hline $\mathrm{Hg}$ & $<0.1$ & $<0.1$ & $<0.1$ \\
\hline $\mathrm{Sr}$ & 9.91 & $<0.1$ & 5.81 \\
\hline $\mathrm{Ba}$ & 32.20 & $<0.1$ & 0.63 \\
\hline Co & 2.50 & $<0.1$ & $<0.1$ \\
\hline $\mathrm{Cd}$ & 0.47 & 0.29 & $<0.1$ \\
\hline
\end{tabular}

$\mathrm{EC}=$ electrical conductivity; $\mathrm{DW}=$ dry weight $\mathrm{TOC}=$ total organic carbon; $\mathrm{TN}=$ total nitrogen; $\mathrm{C} / \mathrm{N}=$ ratio of carbon to nitrogen; $\mathrm{P}, \mathrm{K}, \mathrm{Mg}$-available

organisms are PUFA with the first double bond on C3 and $\mathrm{C} 6$ from the methyl-end. Since fatty acids from this group are indispensable for the normal functioning of metabolic processes, they have to be obtained from a diet [20-23]. Changes in lipid or lipoprotein metabolism can result in the modification of membrane composition and subsequently in changes in its permeability. It may also lead to disruption of signaling networks and could 
Table 2. Experimental design.

\begin{tabular}{|c|c|c|c|}
\hline \multirow{2}{*}{$\begin{array}{l}\text { Experimental } \\
\text { factor }\end{array}$} & \multicolumn{3}{|c|}{ Year (growing season) } \\
\hline & $2013 / 2014$ & $2014 / 2015$ & $2015 / 2016$ \\
\hline $\mathrm{C}$ & \multicolumn{3}{|c|}{ PS +0 (control soil $)$} \\
\hline NPK & $\mathrm{PS}+\mathrm{NPK}$ & $\mathrm{PS}+\mathrm{NPK}$ & $\mathrm{PS}+\mathrm{NPK}$ \\
\hline MS & $\begin{array}{c}\text { PS + MS } \\
\left(155 \mathrm{t} \mathrm{DW} \mathrm{ha}^{-1}\right)\end{array}$ & $\begin{array}{c}\text { PS + MS } \\
\left(155 \mathrm{t} \mathrm{DW} \mathrm{ha}^{-1}\right)\end{array}$ & $\begin{array}{c}\text { PS + MS } \\
\left(155 \text { t DW ha }^{-1}\right)\end{array}$ \\
\hline $\mathrm{BD}$ & $\begin{array}{c}\text { PS + BD } \\
\left(5.1 \mathrm{t} \mathrm{DW} \mathrm{ha}^{-1}\right)\end{array}$ & $\begin{array}{c}\text { PS + BD } \\
\left(5.1 \text { t DW ha }{ }^{-1}\right)\end{array}$ & $\begin{array}{c}\text { PS + BD } \\
\left(5.1 \text { t DW ha }{ }^{-1}\right)\end{array}$ \\
\hline $\mathrm{MS}+\mathrm{BD}$ & $\begin{array}{c}\text { PS + MS+BD } \\
\left(155 \mathrm{t} \mathrm{DW} \mathrm{ha}^{-1}+5.1 \mathrm{t} \mathrm{DW} \mathrm{ha} \mathrm{ha}^{-1}\right)\end{array}$ & $\begin{array}{c}\text { PS + MS+BD } \\
\left(155 \mathrm{t} \mathrm{DW} \mathrm{ha}^{-1}+5.1 \mathrm{t} \text { DW ha-1 }\right)\end{array}$ & $\begin{array}{c}\text { PS + MS+BD } \\
\left(155 \mathrm{t} \mathrm{DW} \mathrm{ha}^{-1}+5.1 \mathrm{t} \mathrm{DW} \mathrm{ha} \mathrm{h}^{-1}\right)\end{array}$ \\
\hline
\end{tabular}

$\mathrm{C}=$ control (podzolic soil - PS without fertilization); $\mathrm{NPK}=\mathrm{PS}+\mathrm{N}, \mathrm{P}, \mathrm{K}, \mathrm{Mg}, \mathrm{Ca}, \mathrm{S}$ (respectively: $120 \mathrm{~N}, 100 \mathrm{P}_{2} \mathrm{O}_{5}, 120 \mathrm{~K}_{2} \mathrm{O}$, $\left.40 \mathrm{MgO}, 60 \mathrm{Ca}, 30 \mathrm{SO}_{2} \mathrm{~kg} \mathrm{ha}^{-1}\right) ; \mathrm{DW}=$ dry weight

be associated with some pathological states such as cancer, cardiovascular, neurodegenerative, and metabolic diseases, and similarly with inflammatory complications [24-25].

Among commonly consumed plant oils and animal fats, rapeseed oil has the most favorable composition and proportions of fatty acids, adjusted for the metabolic requirements of the human organism. Moreover, rapeseed oil has the most favorable percentage contribution of energy of SFA, PUFA, omega-3 (n3) PUFA, and omega-6 (n6) PUFA of vegetable oils to recommended daily intakes for total fat (ERDI-37.7 kJ/g) [23].

The increasing interest in the use of wastes for plant fertilization is not always accompanied by comprehensive research on the effect of waste on the nutritional and health value of plants. The aim of this study was to determine the effect of three years of fertilization with biogas residue and mining waste on OSR yield and the quantitative and qualitative changes in the fatty acids composition. Additionaly, the study determined the effect of the investigated waste materials on the uptake and bioaccumulation of heavy metals in OSR seeds.

\section{Material and Methods}

\section{Field Experiment}

A field experiment was carried out in the growing seasons such as 2013/2014, 2014/2015, and 2015/2016 at the experimental farm in Bezek (N: 51.200696 E: 23.293073) belonging to the University of Life Sciences in Lublin. In 2013 the research work comprised preparing the field, setting up a field experiment, collecting soil samples, and starting preliminary analysis. The experiment was set up in a randomized block design in three replicates (5 treatments, 3 reps, and 15 plots with an area of $37.5 \mathrm{~m}^{2}$ each) on podzolic soil (PS). The particle size distribution of PS was as follows: sand $(2.0-0.05 \mathrm{~mm})$ $=72 \%$, coarse silt $(0.05-0.02 \mathrm{~mm})=14 \%$, fine silt $(0.02-0.002 \mathrm{~mm})=13 \%$, and clay particle size $<0.002 \mathrm{~mm}=1 \%$. The soil was characterized by a low content of total $\mathrm{N}$ and $\mathrm{P}$ as well as a very low content of $\mathrm{K}$ and $\mathrm{Mg}$ (Table 1).

The PS was amended with BD and MS. Based on the following experimental design (Table 2), BD and MS were added (during summer pre-sowing tillage operations on the depth $25 \pm 2 \mathrm{~cm}$ ). Synthetic fertilizers in the conventional fertilization treatment and the waste materials were incorporated into the soil in the fall during the preparation of the field for sowing. The winter OSR cultivar Chagall was sown on August 20-25, 2013, 2014, and 2015. Due to the low class of the soil, the seeding rate was 60 seeds per $\mathrm{m}^{2}$. Nitrogen fertilizer was applied in amide form (urea - $\mathrm{C}-\mathrm{NH}_{2}$ ) and was divided into two doses: one dose of $40 \mathrm{~kg} \mathrm{ha}^{-1}$ was applied immediately after sowing (00 stage $\mathrm{BBCH})$, while the other one $(80 \mathrm{~kg}$ $\mathrm{ha}^{-1}$ ) in the spring at the 29-30 stages $\mathrm{BBCH}$ ). The basis for determining the rate of tested materials was not only mainly $\mathrm{N}$, but also considered the high content of $\mathrm{K}, \mathrm{P}$, $\mathrm{Mg}$, and $\mathrm{Na}$ in $\mathrm{BD}$, as well as high content of $\mathrm{Al}, \mathrm{Fe}, \mathrm{Na}$, and $\mathrm{K}$ in MS (Table 1). The content of the major fertilizer nutrients (NPK) in BD dry weight is many times higher than in MS dry weight. In order to avoid the effect of $\mathrm{N}$ overfertilization, the rates of $\mathrm{BD}$ were lower than the MS rates.

The field experiment scheme from the first vegetative season (2013/2014) was repeated in two subsequent seasons $(2014 / 2015$ and $2015 / 2016)$ in order to determine the influence of subsequent doses of wastes on the yield and quality of OSR (Table 2). The plots were at the same treatments (blocks) in the crop rotation: winter oilseed rape - winter wheat - oats. Annual NPK applications were: $\mathrm{TN}=147, \mathrm{P}=29, \mathrm{~K}=137 \mathrm{~kg} \mathrm{ha}^{-1}$ from $\mathrm{BD}$ and $\mathrm{TN}=558, \mathrm{P}=2.3$, and $\mathrm{K}=51 \mathrm{~kg} \mathrm{ha}^{-1}$ from MS. The very high $\mathrm{C} / \mathrm{N}$ ratio for $\mathrm{MS}$ (77.4) indicates that despite high levels of TN, it was not available to plants

\section{Characteristics of Waste Materials}

BD was collected from a biogas plant of the company Wikana Bioenergia Sp. z o.o. in Poland. The following feedstocks were used for energy production: corn silage $(70 \%)$, sugar bagasse beet $(15 \%)$, pomace of fruit $(5 \%)$, 
wastes from dairy (5\%), and manure (5\%). The type of fermentation is as follows: mesophilic $\left(32-42^{\circ} \mathrm{C}\right)$. This waste is a mixture of water and digested organic matter. The dry matter content in unprocessed BD used in the study was $8-9 \%$ [10]. In subsequent years, BD originated from the same biogas plant, with the substrates for the biogas production from the same suppliers. Moreover, the proportions of substrates and fermentation conditions did not change significantly, which enabled the use of BD with similar parameters in subsequent years (Table 1).

The source of clay minerals was MS originating from carboniferous roof rocks, bottom rocks, or interlayers of the exploited coal seams in a coal mine belonging to the coal company Bogdanka SA in Poland. In petrographic terms, it is a mixture of mainly clays and mudstones rapidly undergoing weathering. These minerals complement organic matter concentrations. The mineral composition of this waste primarily consists of silica $\left(\mathrm{SiO}_{2}=470 \mathrm{~g} \mathrm{~kg}^{-1}\right)$ and aluminum oxide $\left(\mathrm{Al}_{2} \mathrm{O}_{3}=220 \mathrm{~g} \mathrm{~kg}^{-1}\right)$ [9]. In all years, the same MS was used, which was shipped prior to the establishment of the field experiment, stored under cover, and each year the suitable portion was transported to the field. Table 1 shows the properties of the waste materials used in the experiment.

\section{Soil and Waste Analysis}

First (based) soil and waste samples were collected in 2013 immediately before the start of the experiment (Table 1). Soil subsamples were taken from the entire length of the arable layer of the soil $(27 \pm 2 \mathrm{~cm})$ with a stainless steel corer $(2 \mathrm{~cm}$ in diameter). Then, the subsamples from each plot were mixed to obtain a representative sample. The following soil properties were analyzed using Van Reeuwijk's standard laboratory procedures: particle size distribution by the hydrometer method; $\mathrm{pH}$ in $1 \mathrm{M} \mathrm{KCl}$ solution potentiometrically (soil to solution ratio of 1:2.5); and total nitrogen was determined by Kjeldahl's method without the application of Devarda's alloy $(\mathrm{Cu}-\mathrm{Al}-\mathrm{Zn}$ alloy reducer of nitrites and nitrates).

The total organic carbon (TOC) content was determined by the gravimetric method. The soil/BD/ MS was dried at a temperature of $105^{\circ} \mathrm{C}$ to constant weight and then incinerated at $550^{\circ} \mathrm{C}$ and the weight loss was measured. The concentration of plant-available $\mathrm{P}$ and $\mathrm{K}$ were determined by the Egner-Riehm method (KQ/PB-07), available $\mathrm{Mg}$ and $\mathrm{Fe}, \mathrm{Ca}, \mathrm{NaS}-\mathrm{SO}_{4}, \mathrm{~B}, \mathrm{Mn}$, $\mathrm{Cu}$, and $\mathrm{Zn}$ - with the atomic absorption spectrometry (AAS) method after extraction with $0.0125 \mathrm{~mol} / \mathrm{L} \mathrm{CaCl}_{2}$ (PN-R-04020, 1994).

\section{Evaluation Methods of Heavy Metal Bioaccumulation}

Waste and the majority of conventional fertilization were applied in autumn of the preceding year prior to OSR being sown. Due to the required homogenization time of waste with soil, the soil samples for the measurement of heavy metals content were collected in spring 2016, prior to the commencement of OSR vegetation. The seed samples for measuring heavy metal content were collected in 2016, directly after OSR harvesting. The metal and other elemental concentrations in soil and seeds was determined using a START D microwave oven (Milestone, Italy) via a wet method in a mixture of nitric acid $(8 \mathrm{ml})$ and hydrochloric acid $(2 \mathrm{ml})$ at a ratio of $4: 1$.

Analysis of the metals end metalloids $(\mathrm{Cr}, \mathrm{Cu}, \mathrm{Ni}$, $\mathrm{Mn}, \mathrm{Pb}, \mathrm{Cd}, \mathrm{Zn}, \mathrm{Co}, \mathrm{Fe}, \mathrm{Ba}, \mathrm{Al}$, Sr were detected in most samples; other metals end metalloids, e.g., $\mathrm{Hg}$, As, Se, Mo were not detected in most samples) contents were carried out using ICP-OES (Thermo Scientific, ICAP 7000 Series, USA). Evaluation of the accuracy and precision of the analytical procedures used reference materials (Heavy Clay Soil, RTH 953, Promochem). Based on the total contents of elements in the soil and seeds, the bioaccumulation index (BAI) was calculated according to the following formula: BAIx $=\mathrm{SECx} / \mathrm{SOCX}$ ( $\mathrm{x}$ - element, SEC - total concentration in seeds, SOC total concentration in soil).

\section{Yield Analysis}

Each year when OSR were ready to be harvested, whole OSR plants (stubble $15 \mathrm{~cm}$ left in the field) were sampled by hand from three randomly selected locations of each plot with an area of $1 \mathrm{~m}^{2}$. Siliques (pods) were separated from straw manually. Siliques samples were threshed in a WINTERSTEIGER LD 180 laboratory thresher. Seeds and crop residues were weighed separately, converting their yields to a per hectare basis and calculated harvest index $(\mathrm{HI}=$ seeds $/$ residues + seeds). Thousand seeds weight was determined (counting $2 \times 500$ seeds).

\section{Analysis of Nutritional Quality}

The seed samples were subsequently analyzed for their fat and glucosinolate contents, separately for each replicate/plot and the 3 sampling sites $\left(1 \mathrm{~m}^{2}\right)$. Fat was determined by modified Soxhlet method (ISO 659:2009). The glucosinolates content was determined by method based on extraction by methanol, purification and enzymatic desulfatation, determination using reversedphase chromatography (ISO 9167-1:1992). This data was the basis for calibration OmegAnalizer G produced by Bruins Instruments NIR (near infrared) grain analyzers. Wavelength range is $730-1100 \mathrm{~nm}$ transmission with $5 \mathrm{~nm}$ scan increment. Automatic feed with multiple sub-sample measurements allow you to get repeatable results for the tested grain parameters.

\section{Preparation of Fatty Acid Methyl Esters (FAME)}

The seed samples for the measurement of fatty acids (FA) composition and heavy metal content were 
Table 3. Effect of biogas residue (BD) and mining waste (MS) fertilization on OSR yields and seeds quality (mean, $\mathrm{n}=3$ ).

\begin{tabular}{|c|c|c|c|c|c|c|}
\hline \multirow{2}{*}{ Parameter } & \multirow{2}{*}{ Year } & \multicolumn{5}{|c|}{ Type of fertilization } \\
\hline & & $\mathrm{C}$ & NPK & MS & $\mathrm{BD}$ & $\mathrm{MS}+\mathrm{BD}$ \\
\hline \multirow{3}{*}{$\begin{array}{l}\text { OSR seeds yield } \\
\qquad\left(\mathrm{t} \mathrm{ha}^{-1}\right)\end{array}$} & 2014 & $1.64^{\mathrm{a}}$ & $2.76^{\mathrm{d}}$ & $2.12^{\mathrm{b}}$ & $2.21^{\mathrm{bc}}$ & $2.59^{\mathrm{cd}}$ \\
\hline & 2015 & $1.78^{\mathrm{a}}$ & $2.95^{\mathrm{c}}$ & $2.31^{\mathrm{b}}$ & $2.38^{\mathrm{b}}$ & $2.92^{\mathrm{c}}$ \\
\hline & 2016 & $1.69^{\mathrm{a}}$ & $2.88^{c}$ & $2.40^{\mathrm{b}}$ & $2.27^{\mathrm{b}}$ & $3.05^{\mathrm{c}}$ \\
\hline \multirow{3}{*}{$\begin{array}{l}\text { Harvest residues } \\
\qquad\left(\mathrm{t} \mathrm{ha}^{-1}\right)\end{array}$} & 2014 & $2.94^{\mathrm{a}}$ & $6.39^{c}$ & $4.15^{\mathrm{b}}$ & $4.30^{\mathrm{b}}$ & $5.41^{\mathrm{c}}$ \\
\hline & 2015 & $3.18^{\mathrm{a}}$ & $6.65^{\mathrm{c}}$ & $4.58^{\mathrm{b}}$ & $4.72^{b}$ & $6.10^{\mathrm{c}}$ \\
\hline & 2016 & $2.90^{\mathrm{a}}$ & $6.40^{c}$ & $4.41^{\mathrm{b}}$ & $4.71^{\mathrm{b}}$ & $5.86^{\mathrm{c}}$ \\
\hline \multirow{3}{*}{ Harvest index - HI } & 2014 & $0.36^{\mathrm{c}}$ & $0.30^{\mathrm{a}}$ & $0.34^{\mathrm{bc}}$ & $0.34^{\mathrm{bc}}$ & $0.32^{\mathrm{ab}}$ \\
\hline & 2015 & $0.36^{\mathrm{c}}$ & $0.31^{\mathrm{a}}$ & $0.34^{\mathrm{bc}}$ & $0.34^{\mathrm{bc}}$ & $0.32^{\mathrm{ab}}$ \\
\hline & 2016 & $0.37^{\mathrm{c}}$ & $0.31^{\mathrm{a}}$ & $0.35^{\mathrm{b}}$ & $0.33^{\mathrm{ab}}$ & $0.34^{\mathrm{abc}}$ \\
\hline \multirow{3}{*}{$\begin{array}{l}\text { Thousand seeds weight (TSW) } \\
\text { (g) }\end{array}$} & 2014 & $5.43^{b}$ & $4.85^{\mathrm{a}}$ & $4.87^{\mathrm{a}}$ & $5.37^{\mathrm{b}}$ & $5.08^{\mathrm{ab}}$ \\
\hline & 2015 & $5.28^{\mathrm{a}}$ & $5.01^{\mathrm{a}}$ & $4.95^{\mathrm{a}}$ & $5.35^{\mathrm{a}}$ & $5.20^{\mathrm{a}}$ \\
\hline & 2016 & $5.31^{\mathrm{b}}$ & $4.96^{\mathrm{a}}$ & $5.14^{\mathrm{ab}}$ & $5.09^{\mathrm{ab}}$ & $5.32^{\mathrm{b}}$ \\
\hline \multirow{3}{*}{$\begin{array}{l}\text { Fat content } \\
\quad(\%)\end{array}$} & 2014 & $44.1^{\mathrm{a}}$ & $43.9^{\mathrm{a}}$ & $43.7^{\mathrm{a}}$ & $44.1^{\mathrm{a}}$ & $44.0^{\mathrm{a}}$ \\
\hline & 2015 & $44.9^{\mathrm{b}}$ & $44.4^{\mathrm{b}}$ & $44.6^{\mathrm{b}}$ & $43.1^{\mathrm{a}}$ & $44.2^{\mathrm{b}}$ \\
\hline & 2016 & $44.7^{\mathrm{bc}}$ & $43.0^{\mathrm{a}}$ & $45.1^{\mathrm{cd}}$ & $45.8^{\mathrm{d}}$ & $43.9^{\mathrm{ab}}$ \\
\hline \multirow{3}{*}{$\begin{array}{l}\text { Fat yield } \\
\left(\mathrm{t} \mathrm{ha}^{-1}\right)\end{array}$} & 2014 & $0.72^{\mathrm{a}}$ & $1.21^{\mathrm{c}}$ & $0.93^{\mathrm{b}}$ & $0.98^{\mathrm{b}}$ & $1.14^{\mathrm{c}}$ \\
\hline & 2015 & $0.80^{\mathrm{a}}$ & $1.31^{\mathrm{c}}$ & $1.03^{\mathrm{b}}$ & $1.03^{b}$ & $1.29^{\mathrm{c}}$ \\
\hline & 2016 & $0.76^{\mathrm{a}}$ & $1.24^{\mathrm{cd}}$ & $1.08^{\mathrm{bc}}$ & $1.04^{\mathrm{b}}$ & $1.34^{\mathrm{d}}$ \\
\hline \multirow{3}{*}{$\begin{array}{l}\text { Glucosinolates } \\
\qquad\left(\mu \mathrm{mol} \mathrm{g}{ }^{-1}\right)\end{array}$} & 2014 & $13.3^{\mathrm{ab}}$ & $14.7^{\mathrm{c}}$ & $12.9^{\mathrm{a}}$ & $14.4^{\mathrm{bc}}$ & $13.5^{\mathrm{abc}}$ \\
\hline & 2015 & $12.7^{\mathrm{ab}}$ & $11.5^{\mathrm{a}}$ & $12.7^{\mathrm{ab}}$ & $15.7^{\mathrm{d}}$ & $14.3^{\mathrm{c}}$ \\
\hline & 2016 & $12.4^{\mathrm{a}}$ & $12.8^{\mathrm{a}}$ & $14.0^{\mathrm{ab}}$ & $14.9^{\mathrm{b}}$ & $14.6^{\mathrm{b}}$ \\
\hline
\end{tabular}

$\mathrm{C}=$ control (podzolic soil - PS without fertilization); $\mathrm{NPK}=\mathrm{PS}+\mathrm{N}, \mathrm{P}, \mathrm{K}, \mathrm{Mg}, \mathrm{Ca}, \mathrm{S}$ (respectively: $120 \mathrm{~N}, 100 \mathrm{P}_{2} \mathrm{O}_{5}, 120 \mathrm{~K}_{2} \mathrm{O}$, $\left.40 \mathrm{MgO}, 60 \mathrm{Ca}, 30 \mathrm{SO}_{2} \mathrm{~kg} \mathrm{ha}^{-1}\right) ; \mathrm{MS}=\mathrm{PS}+155 \mathrm{t} \mathrm{DW}$ of MS ha- ${ }^{-1}$ BD $=\mathrm{PS}+5.1 \mathrm{t} \mathrm{DW}$ of $\mathrm{BD} \mathrm{ha}^{-1} ; \mathrm{MS}+\mathrm{BD}=\mathrm{PS}+155 \mathrm{t} \mathrm{DW}$

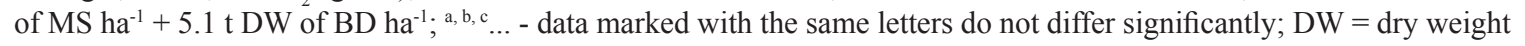

collected in 2016, directly after OSR harvesting. Fatty acids (FA) composition of the fats was determined as their corresponding methyl esters. Preparation of FAME was carried out according to the PN-ISO5509 method. Per $100 \mathrm{mg}$ of fat we added $4 \mathrm{ml}$ of methanolic potassium hydroxide solution. Then the sample was heated and stirred at $85-95^{\circ} \mathrm{C}$. After cooling, $4 \mathrm{ml}$ of methanol was added to a solution of boron trifluoride, heated again at $85-95^{\circ} \mathrm{C}$ for $10 \mathrm{~min}$, and cooled rapidly. One $\mathrm{ml}$ of hexane was added to the cooled ampoule. After stirring, $2 \mathrm{ml}$ of saturated sodium chloride solution was added and mixed again. Using a pipette, we collected the organic layer (hexane) to an Eppendorf tube and dried it by adding anhydrous sodium sulfate. $100 \mu \mathrm{l}$ from an Eppendorf tube was transferred to a vial containing $900 \mu \mathrm{l}$ of hexane and placed in the autosampler. Analysis of FAME was performed by gas chromatography (PN-EN ISO129661:2015-01) with a Varian 450-GC gas chromatograph. Dispenser temperature $-250^{\circ} \mathrm{C}$, split $-1: 50$, column temperature $-200^{\circ} \mathrm{C}$ for 10 minutes and $3{ }^{\circ} \mathrm{C} / \mathrm{min}$ to $240^{\circ} \mathrm{C}$. Total analysis time was $28 \mathrm{~min}$. Type of carrier gas - Hel, Carrier gas flow $-2.5 \mathrm{ml} / \mathrm{min}$, detector temperature (FID) $-300^{\circ} \mathrm{C}$, injection volume $-1 \mu$ l.

\section{Statistical Analysis}

All experimental results were represented as mean of three parallel replicates. One-way analysis of variance (ANOVA) and Tukey's post hoc test were used to compare groups within different elicitors. $\alpha$ values $<0.05$ were regarded as significant. Tukey's HSD test (intermediate between LSD test and Scheffe's test) is an easy method for determining the critical significance of differences and is adequate in the simple factors systems (equal sample sizes per group).

\section{Results and Discussion}

\section{Yield and Nutrient Content}

The adding of wastes to the tested soil (PS) significantly affected yield and the structure of OSR yield. In all years of the study the mining waste (MS) and biogas digestate (BD) significantly increased the seed and biomass yield compared to the control treatment (C - without fertilization) (Table 3). In 2014 
Table 4. Effect of three-year fertilization of biogas residue (BD) and mining waste (MS) on the fatty acids (FA) composition of OSR seeds (content of FA in \% of total FAME (FA Methyl Esters).

\begin{tabular}{|c|c|c|c|c|c|}
\hline \multirow{2}{*}{ Fatty acid } & \multicolumn{5}{|c|}{ Type of fertilization } \\
\hline & $\mathrm{C}$ & NPK & MS & $\mathrm{BD}$ & $\mathrm{MS}+\mathrm{BD}$ \\
\hline Palmitic C16:0 & $4.34^{\mathrm{a}}$ & $4.53^{\mathrm{b}}$ & $4.51^{\mathrm{b}}$ & $4.42^{\mathrm{ab}}$ & $4.30^{\mathrm{a}}$ \\
\hline Palmitooleic C16:1 & $0.26^{\mathrm{a}}$ & $0.29^{\mathrm{b}}$ & $0.28^{\mathrm{ab}}$ & $0.27^{\mathrm{ab}}$ & $0.25^{\mathrm{a}}$ \\
\hline Stearic C18:0 & $1.54^{\mathrm{ab}}$ & $1.51^{\mathrm{a}}$ & $1.62^{\mathrm{b}}$ & $1.59^{\mathrm{b}}$ & $1.56^{\mathrm{ab}}$ \\
\hline $\begin{array}{l}\text { Oleic C18:1 } \\
(+ \text { Elaidic })\end{array}$ & $62.65^{b}$ & $60.33^{\mathrm{a}}$ & $60.40^{\mathrm{a}}$ & $61.61^{\mathrm{ab}}$ & $62.53^{b}$ \\
\hline $\begin{array}{c}\text { Linoleic C18:2 } \\
\text { (+ Linolenelaidic) }\end{array}$ & $20.05^{\mathrm{a}}$ & $21.26^{\mathrm{b}}$ & $21.16^{\mathrm{b}}$ & $20.59^{\mathrm{ab}}$ & $20.01^{\mathrm{a}}$ \\
\hline$\alpha$ - Linoleic C18:3n3 & $9.11^{\mathrm{a}}$ & $9.90^{\mathrm{b}}$ & $9.82^{\mathrm{b}}$ & $9.30^{\mathrm{a}}$ & $9.05^{\mathrm{a}}$ \\
\hline Arachidic C20:0 & $0.46^{\mathrm{a}}$ & $0.48^{\mathrm{ab}}$ & $0.49^{\mathrm{ab}}$ & $0.49^{\mathrm{ab}}$ & $0.50^{\mathrm{b}}$ \\
\hline Arachidoic C20:4 & $1.01^{\mathrm{a}}$ & $1.04^{\mathrm{ab}}$ & $1.08^{\mathrm{b}}$ & $1.08^{\mathrm{b}}$ & $1.13^{\mathrm{c}}$ \\
\hline Behenic C22:0 & $0.24^{\mathrm{a}}$ & $0.25^{\mathrm{a}}$ & $0.25^{\mathrm{a}}$ & $0.26^{\mathrm{ab}}$ & $0.28^{\mathrm{b}}$ \\
\hline$\Sigma$ SFA $(\%$ FA $)$ & $6.71^{\mathrm{a}}$ & $6.93^{\mathrm{ab}}$ & $7.03^{\mathrm{b}}$ & $6.91^{\mathrm{ab}}$ & $6.84^{\mathrm{ab}}$ \\
\hline$\Sigma$ MUFA $(\%$ FA) & $64.01^{\mathrm{c}}$ & $61.75^{\mathrm{a}}$ & $61.85^{\mathrm{ab}}$ & $63.04^{\mathrm{bc}}$ & $63.99^{c}$ \\
\hline$\Sigma$ PUFA $(\%$ FA) & $29.16^{\mathrm{a}}$ & $31.22^{\mathrm{b}}$ & $31.04^{b}$ & $29.95^{\mathrm{a}}$ & $29.12^{\mathrm{a}}$ \\
\hline UFA/SFA & $13.89^{\mathrm{c}}$ & $13.42^{\mathrm{ab}}$ & $13.21^{\mathrm{a}}$ & $13.46^{\mathrm{ab}}$ & $13.61^{\mathrm{bc}}$ \\
\hline $\mathrm{n} 3(\% \mathrm{FA})$ & $9.11^{\mathrm{a}}$ & $9.90^{\mathrm{b}}$ & $9.82^{\mathrm{b}}$ & $9.30^{\mathrm{a}}$ & $9.05^{\mathrm{a}}$ \\
\hline n6 (\% FA) & $20.05^{\mathrm{a}}$ & $21.26^{\mathrm{b}}$ & $21.16^{\mathrm{b}}$ & $20.59^{\mathrm{ab}}$ & $20.01^{\mathrm{a}}$ \\
\hline $\mathrm{n} 6 / \mathrm{n} 3$ & 2.20 & 2.15 & 2. 15 & 2.21 & 2.21 \\
\hline
\end{tabular}

$\mathrm{C}=$ control (podzolic soil- PS without fertilization); $\mathrm{NPK}=\mathrm{PS}+\mathrm{N}, \mathrm{P}, \mathrm{K}, \mathrm{Mg}, \mathrm{Ca}, \mathrm{S}$ (respectively: $120 \mathrm{~N}, 100 \mathrm{P}_{2} \mathrm{O}_{5}, 120 \mathrm{~K}_{2} \mathrm{O}$, $\left.40 \mathrm{MgO}, 60 \mathrm{Ca}, 30 \mathrm{SO}_{2} \mathrm{~kg} \mathrm{ha}^{-1}\right) ; \mathrm{MS}=\mathrm{PS}+155 \mathrm{t} \mathrm{DW}$ of MS ha- ${ }^{-1} ; \mathrm{BD}=\mathrm{PS}+5.1 \mathrm{t} \mathrm{DW}$ of BD ha- ${ }^{-1} \mathrm{MS}+\mathrm{BD}=\mathrm{PS}+155 \mathrm{t} \mathrm{DW}$ of MS ha- $\mathrm{M}^{-1}+1 \mathrm{t} \mathrm{DW}$ of BD ha ${ }^{-1} ;{ }^{\mathrm{a}, \mathrm{b}, \mathrm{c}} \ldots$ - - data marked with the same letters do not differ significantly; DW = dry weight

and 2015, the NPK increased the OSR seed yield compared to C, MS, BD (significant differences), and MS+BD (insignificant differences). In 2016 the highest seed yield was obtained after coapplication of wastes (MS+BD) (significant compared to C, MS, BD, and insignificant compared to NPK). The significant highest straw and other harvest residue weight was observed on the plots with NPK and MS+BD fertilization compared to $\mathrm{C}$, MS, and $\mathrm{BD}$. Moreover, a significantly lower harvest index (HI) was obtained by fertilizing with NPK compared to C, MS, and BD (excepting BD in 2016). The subsequent doses of MS and MS+BD in the following years deteriorated the HI (Table 3).

The least favorable HI in the NPK treatment is probably caused by too high nitrogen availability. Nitrogen is used by the plants for vegetative development. The majority of nutrient resources are depleted in the early developmental stages and their deficiency occurs in the silique filling phases. Similar relationships were observed in the parallel experiment with winter wheat [10].

In the first year, NPK and MS significantly increased thousand seed weight (TSW) compared to C. In the second year differences were similar to the first year but were statistically insignificant. In the third year a significant reduction of TSW occurred only after NPK fertilization (Table 3).

In 2014 the content of fat in OSR seeds slightly depended on the type of fertilization. In 2015 fertilization with $\mathrm{BD}$ significantly reduced the fat content compared to other plots, whereas in 2016 the OSR seeds fat content in MS and BD was significantly higher than in NPK and MS+BD treatments. The conversion of the fat content to its amount obtained from one hectare demonstrates that statistically the most efficient in terms of the total fat yield was NPK and MS+BD in each year (Table 3).

In the first year of the experiment, NPK and BD increased glucosinolate content the most in comparison to $\mathrm{C}$. However, in the case of $\mathrm{BD}$, the difference was statistically insignificant. In the two next years, a significant increase in glucosinolate content occurred under $\mathrm{BD}$ and $\mathrm{MS}+\mathrm{BD}$ fertilization. This was probably caused by high $\mathrm{S}_{-} \mathrm{SO}_{4}$ content in $\mathrm{BD}$ and accumulation of this compound in the soil in subsequent years of waste use. The studies of Malhi et al. [26] and Ma et al. [27] indicate that the most yielding factors are $\mathrm{N}$ and $\mathrm{S}$ combined in a 10:2 ratio in comparison to other forms of mineral fertilization, organic fertilization, and their combinations. One of the most important elements for OSR fertilization is sulfur and also $\mathrm{B}$ and $\mathrm{Cu}$. A dose of 
$\mathrm{S}$ of $40-60 \mathrm{~kg} \mathrm{ha}^{-1}$ may increase OSR yield by $12 \%$, whereas $\mathrm{B}$ or $\mathrm{B}+\mathrm{Cu}$ by approximately $10 \%$. What is more, these microelements in higher doses can increase oil content in OSR. Additionally, S fertilization increases glucosinolate content in seeds [28]. In the work of Wang et al. [29], the use of $\mathrm{Zn}$ in the standard OSR fertilization increased seed yield by 5 to $16 \%$ and oil yield by 6 to $19 \%$. The application of $\mathrm{Zn}$ fertilizer increased the concentrations of total oil, oleic acid, and linoleic acid in rapeseed, but reduced stearic acid concentration.

\section{FA Composition}

OSR fat contained mostly oleic acid, including its trans isomer form (the trans isomer of oleic acid), i.e., elaidic acid classified as a n9 MUFA. The highest oleic acid content was observed in seeds from control fields. The significant decrease of its content in relation to $\mathrm{C}$ occurred under NPK and MS. The lowest decrease in comparison to $\mathrm{C}$ occurred under $\mathrm{MS}+\mathrm{BD}$ fertilization (Table 4). At the same time, we noticed a significant increase of $\alpha$-Linoleic, Linoleic + Linolenelaidic, Palmitic, and Palmitooleic acid content in variants NPK and $\mathrm{MS}$ in comparison to $\mathrm{C}, \mathrm{BD}$, and MS+BD. NPK fertilization significantly reduced the content of stearic acid in comparison to MS and BD. Wastes fertilization (in particular MS+BD) increased the percentage content of arachidic, arachidonic, and behenic acids in relation to $\mathrm{C}$, and sometimes in relation to NPK.

An important parameter within the context of evolutionary aspects of the human diet is the FA n6/n3 ratio. The origin ratio of $\mathrm{n} 6 / \mathrm{n} 3$ was 1 . In recent years, the increase of n6 PUFA in relation to $n 3$ in the diet is considered to be an adverse civilization phenomenon $[22,30]$. In our study BD and MS+BD decreased the content of $n 3$ and $n 6$ in the total FA compared to NPK and MS. The n6/n3 relationship varied in a narrow range $(2.15-2.21)$. The most preferred $n 6 / n 3$ ratio was obtained after applying NPK and MS, but the differences between fertilization methods were not significant (Table 4). Usually, the ratio of $n 6 / \mathrm{n} 3$ for OSR ranges from 0.5 to 2.6 [31-32] but it may drop to 16.3. Despite this fact, the oil obtained from OSR is characterized by one of the best FA compositions among plant oils [23]. The content of $n 6$ and $n 3$ PUFA and other FA is primarily genetically determined [32-33]. However, our studies show the significant effect of fertilization on $\mathrm{n} 3$ and $\mathrm{n} 6$ percentages. $\mathrm{BD}$ and $\mathrm{MS}+\mathrm{BD}$ decreased the share of $\mathrm{n} 3$ and $\mathrm{n} 6$ in the total content of FAs compared to C, NPK, and MS. Onemli [31] provides that along with the increase of the amount of organic matter in the soil, the oleic acid content increases.

The unsaturated (UFA)/saturated (SFA) ratio of coldpressed oil from pomagranate seeds in a Khoddami et al. [34] study varied between 12.43 and 13.07. In our study, this ratio amounted to 13.21 (MS) - 13.89 (C). Furthermore, NPK and MS increased the PUFA and decreased MUFA in relation to $\mathrm{C}, \mathrm{BD}$, and $\mathrm{MS}+\mathrm{BD}$ (Table 4). Salama et al. [35], who studied the content
Table S1. Heavy metal contents $\left(\mathrm{mg} \mathrm{kg}^{-1}\right)$ in OSR seeds after three-year fertilization with biogas residue (BD) and mining waste (MS) $(\mathrm{n}=3)$.

\begin{tabular}{|c|c|c|c|c|c|}
\hline Element & \multicolumn{5}{|c|}{ Type of fertilization } \\
\hline & $\mathrm{C}$ & NPK & MS & BD & MS+BD \\
\hline $\mathrm{Al}$ & 104.38 & 83.29 & 70.85 & 85.45 & 98.82 \\
\hline $\mathrm{Mn}$ & 47.24 & 35.31 & 43.68 & 75.84 & 41.58 \\
\hline $\mathrm{Fe}$ & 53.90 & 46.49 & 44.43 & 47.51 & 48.43 \\
\hline $\mathrm{Zn}$ & 31.39 & 26.08 & 29.08 & 35.31 & 29.92 \\
\hline $\mathrm{Sr}$ & 16.59 & 13.38 & 17.26 & 15.73 & 19.23 \\
\hline $\mathrm{B}$ & 26.54 & 8.06 & 12.51 & 9.26 & 5.69 \\
\hline $\mathrm{Ba}$ & 5.83 & 5.77 & 4.93 & 11.09 & 6.05 \\
\hline $\mathrm{Cu}$ & 6.26 & 6.67 & 6.17 & 5.48 & 6.76 \\
\hline $\mathrm{Ni}$ & 1.26 & 1.16 & 3.42 & 1.72 & 2.30 \\
\hline $\mathrm{Cr}$ & 2.09 & 2.17 & 1.97 & 1.92 & 1.51 \\
\hline $\mathrm{Pb}$ & 0.21 & 0.18 & 0.17 & 0.20 & 0.14 \\
\hline $\mathrm{Co}$ & 0.06 & 0.02 & 0.12 & 0.09 & 0.11 \\
\hline $\mathrm{Cd}$ & 0.05 & 0.05 & 0.06 & 0.06 & 0.06 \\
\hline $\mathrm{E}$ & 295,80 & 228,63 & 234,64 & 289,66 & 260,59 \\
\hline $\mathrm{Con}$ & $(\mathrm{p} 0 \mathrm{z}$ & $\mathrm{c} 5 \mathrm{l}-\mathrm{PS}$ & & \\
\hline
\end{tabular}

$\mathrm{C}=$ control (podzolic soil - PS without fertilization); $\mathrm{NPK}=\mathrm{PS}+\mathrm{N}, \mathrm{P}, \mathrm{K}, \mathrm{Mg}, \mathrm{Ca}, \mathrm{S}$ (respectively: $120 \mathrm{~N}$, $100 \mathrm{P}_{2} \mathrm{O}_{5}, 120 \mathrm{~K}_{2} \mathrm{O}, 40 \mathrm{MgO}, 60 \mathrm{Ca}, 30 \mathrm{SO}_{2} \mathrm{~kg} \mathrm{ha}^{-1}$ ); $\mathrm{MS}=\mathrm{PS}+155 \mathrm{t} \mathrm{DW}$ of MS ha ${ }^{-1} ; \mathrm{BD}=\mathrm{PS}+5.1 \mathrm{t} \mathrm{DW}$ of $\mathrm{BD} \mathrm{ha}{ }^{-1} ; \mathrm{MS}+\mathrm{BD}=\mathrm{PS}+155 \mathrm{t} \mathrm{DW}$ of $\mathrm{MS} \mathrm{ha}^{-1}+5.1 \mathrm{t} \mathrm{DW}$ of BD ha ${ }^{-1}$

and composition of oil in black sesame seeds (BS), determined that biofertilizers and micronutrients can increase oil content in BS by up to $20 \%$ compared with control treatment. Furthermore, the fertilization used in their experiment increased the oleic acid content by $27 \%$ and linoleic acid by up to $33 \%$ as compared to control. In the work of Wang et al. [29], the use of $\mathrm{Zn}$ for standard OSR fertilization increased seed yield by 5.0 to $16.0 \%$ and oil yield by 6.2 to $19.5 \%$. The application of $\mathrm{Zn}$ fertilizer increased the concentrations of total oil, oleic acid, and linoleic acid in rapeseed, but reduced stearic acid concentration.

\section{Heavy Metal Contents and Bioaccumulation Index (BAI)}

After three years of conventional fertilization or waste fertilization the content of heavy metals in OSR seeds as well as in the soil did not (in most cases) exceed the international permissible limits of heavy metals concentration in soil and plants (in reference to WHO (1996), as well as with reference to the EU Commission regulation No. 1275/2013 of 6-FAOLex [34]. The exception was Al, Fe, and $\mathrm{Cr}$ (NPK slightly increased $\mathrm{Cr}$ content compared to control) and $\mathrm{Cd}$ in seeds, whose 
Table S2. Heavy metal contents $\left(\mathrm{mg} \mathrm{kg}^{-1}\right)$ in soil after three-year fertilization with biogas residue (BD) and mining waste (MS) $(\mathrm{n}=3)$.

\begin{tabular}{|c|c|c|c|c|c|}
\hline \multirow{2}{*}{ Element } & \multicolumn{5}{|c|}{ Type of fertilization } \\
\hline & $\mathrm{C}$ & NPK & MS & $\mathrm{BD}$ & $\mathrm{MS}+\mathrm{BD}$ \\
\hline $\mathrm{Al}$ & 4665.82 & 4466.97 & 5174.67 & 4172.95 & 5184.63 \\
\hline $\mathrm{Mn}$ & 231.70 & 191.18 & 204.19 & 212.87 & 227.53 \\
\hline $\mathrm{Fe}$ & 3572.55 & 4206.13 & 3690.67 & 3088.86 & 4224.57 \\
\hline $\mathrm{Zn}$ & 14.65 & 18.83 & 16.73 & 15.20 & 19.68 \\
\hline $\mathrm{Sr}$ & 9.91 & 11.53 & 17.75 & 7.85 & 27.66 \\
\hline B & 12.16 & 11.84 & 10.09 & 7.46 & 11.89 \\
\hline $\mathrm{Ba}$ & 32.20 & 32.89 & 35.27 & 30.36 & 51.42 \\
\hline $\mathrm{Cu}$ & 2.85 & 4.20 & 6.61 & 3.13 & 7.07 \\
\hline $\mathrm{Ni}$ & 11.55 & 8.76 & 9.10 & 8.60 & 12.09 \\
\hline $\mathrm{Cr}$ & 10.45 & 13.54 & 12.99 & 9.35 & 18.55 \\
\hline $\mathrm{Pb}$ & 10.26 & 10.68 & 11.27 & 9.61 & 14.18 \\
\hline Co & 2.50 & 2.26 & 2.90 & 1.97 & 4.09 \\
\hline $\mathrm{Cd}$ & 0.47 & 0.57 & 0.42 & 0.39 & 0.48 \\
\hline$\sum$ & 8577,07 & 8979,37 & 9192,66 & 7568,59 & 9803,84 \\
\hline
\end{tabular}

$\mathrm{C}=$ control (podzolic soil - PS without fertilization); $\mathrm{NPK}=\mathrm{PS}+\mathrm{N}, \mathrm{P}, \mathrm{K}, \mathrm{Mg}, \mathrm{Ca}, \mathrm{S}$ (respectively: $120 \mathrm{~N}$ $100 \mathrm{P}_{2} \mathrm{O}_{5}, 120 \mathrm{~K}_{2} \mathrm{O}, 40 \mathrm{MgO}, 60 \mathrm{Ca}, 30 \mathrm{SO}_{2} \mathrm{~kg} \mathrm{ha}^{-1}$ ); $\mathrm{MS}=\mathrm{PS}+155 \mathrm{tDW}$ of MS ha ${ }^{-1} ; \mathrm{BD}=\mathrm{PS}+5.1 \mathrm{t} \mathrm{DW}$ of $\mathrm{BD} \mathrm{ha}{ }^{-1} ; \mathrm{MS}+\mathrm{BD}=\mathrm{PS}+155 \mathrm{t} \mathrm{DW}$ of $\mathrm{MS} \mathrm{ha}^{-1}+5.1 \mathrm{t} \mathrm{DW}$ of BD ha'

concentration was recorded above the permissible limit set by WHO. However, this had no connection with the use of waste to fertilize OSR, because conventional fertilization and waste decreased the content of these elements in seeds compared to control (Tables S1, S2, and 5). NPK and BD decreased $\mathrm{Al}$ content in soil compared to $\mathrm{C}$ (Table $\mathrm{S} 2$ ).

The content of other elements in soil and seeds of OSR had no clear differences related to the type of fertilization and were difficult to interpret (Table S1 and S2), therefore the BAI was calculated (Table 5). Among the analyzed heavy metals, the highest BAI (regardless of fertilization) was found in the case of $\mathrm{Cu}, \mathrm{Zn}, \mathrm{B}$, and Sr. The most preferred form of fertilization in reducing heavy metal accumulation was MS+BD and NPK. Fertilization of NPK in the highest degree reduced BAI of $\mathrm{Zn}, \mathrm{B}, \mathrm{Mn}, \mathrm{Cd}, \mathrm{Co}$, and Fe compared to control and waste fertilization. Fertilization of $\mathrm{MS}+\mathrm{BD}$ reduced BAI of $\mathrm{Cu}, \mathrm{Sr}, \mathrm{Cr}, \mathrm{Ba}$, and $\mathrm{Pb}$ compared to $\mathrm{C}$ and NPK, and $\mathrm{B}, \mathrm{Mn}$, compared to $\mathrm{C}, \mathrm{MS}$ and BD. Differences were statistically significant but not in all cases. The mean BAI for all elements demonstrates that the lowest accumulation of elements occurred on the plots fertilized with $\mathrm{MS}+\mathrm{BD}$ and the highest on the plots without fertilization (Table 5).
Table 5. Heavy metal bioaccumulation index (BAI) calculated according to the following formula: $\mathrm{BAIx}=\mathrm{SECx} / \mathrm{SOCx}$ (x-element; SEC-total concentration in seeds; SOC-total concentration in soil) $(n=3)$.

\begin{tabular}{|c|c|c|c|c|c|}
\hline \multirow{2}{*}{ Element } & \multicolumn{5}{|c|}{ Type of fertilization } \\
\cline { 2 - 6 } & $\mathrm{C}$ & NPK & MS & BD & MS+BD \\
\hline $\mathrm{Cu}$ & $2.19^{\mathrm{c}}$ & $1.59^{\mathrm{b}}$ & $0.93^{\mathrm{a}}$ & $1.75^{\mathrm{b}}$ & $0.96^{\mathrm{a}}$ \\
\hline $\mathrm{Zn}$ & $2.14^{\mathrm{c}}$ & $1.39^{\mathrm{a}}$ & $1.74^{\mathrm{b}}$ & $2.32^{\mathrm{c}}$ & $1.52^{\mathrm{ab}}$ \\
\hline $\mathrm{B}$ & $2.18^{\mathrm{a}}$ & $0.68^{\mathrm{a}}$ & $1.24^{\mathrm{b}}$ & $1.24^{\mathrm{b}}$ & $0.48^{\mathrm{a}}$ \\
\hline $\mathrm{Sr}$ & $1.67^{\mathrm{c}}$ & $1.16^{\mathrm{b}}$ & $0.97^{\mathrm{ab}}$ & $2.00^{\mathrm{d}}$ & $0.70^{\mathrm{a}}$ \\
\hline $\mathrm{Mn}$ & $0.20^{\mathrm{a}}$ & $0.18^{\mathrm{a}}$ & $0.21^{\mathrm{b}}$ & $0.36^{\mathrm{c}}$ & $0.18^{\mathrm{a}}$ \\
\hline $\mathrm{Cr}$ & $0.20^{\mathrm{c}}$ & $0.16^{\mathrm{b}}$ & $0.15^{\mathrm{b}}$ & $0.20^{\mathrm{c}}$ & $0.08^{\mathrm{a}}$ \\
\hline $\mathrm{Ba}$ & $0.18^{\mathrm{b}}$ & $0.18^{\mathrm{b}}$ & $0.14^{\mathrm{a}}$ & $0.37^{\mathrm{c}}$ & $0.12^{\mathrm{a}}$ \\
\hline $\mathrm{Ni}$ & $0.11^{\mathrm{a}}$ & $0.13^{\mathrm{a}}$ & $0.38^{\mathrm{c}}$ & $0.20^{\mathrm{b}}$ & $0.19^{\mathrm{b}}$ \\
\hline $\mathrm{Cd}$ & $0.10^{\mathrm{ab}}$ & $0.08^{\mathrm{a}}$ & $0.14^{\mathrm{c}}$ & $0.15^{\mathrm{c}}$ & $0.12^{\mathrm{bc}}$ \\
\hline $\mathrm{Co}$ & $0.025^{\mathrm{b}}$ & $0.011^{\mathrm{a}}$ & $0.040^{\mathrm{c}}$ & $0.046^{\mathrm{c}}$ & $0.026^{\mathrm{b}}$ \\
\hline $\mathrm{Al}$ & $0.022^{\mathrm{b}}$ & $0.019^{\mathrm{b}}$ & $0.014^{\mathrm{a}}$ & $0.021^{\mathrm{b}}$ & $0.019^{\mathrm{b}}$ \\
\hline $\mathrm{Pb}$ & $0.020^{\mathrm{b}}$ & $0.017^{\mathrm{b}}$ & $0.015^{\mathrm{ab}}$ & $0.021^{\mathrm{b}}$ & $0.010^{\mathrm{a}}$ \\
\hline $\mathrm{Fe}$ & $0.015^{\mathrm{b}}$ & $0.011^{\mathrm{a}}$ & $0.012^{\mathrm{ab}}$ & $0.015^{\mathrm{b}}$ & $0.012^{\mathrm{ab}}$ \\
\hline $\mathrm{Avarage}$ & 0.70 & 0.43 & 0.46 & 0.67 & 0.34 \\
\hline
\end{tabular}

$\mathrm{C}=$ control (podzolic soil - PS without fertilization); $\mathrm{NPK}=\mathrm{PS}+\mathrm{N}, \mathrm{P}, \mathrm{K}, \mathrm{Mg}, \mathrm{Ca}, \mathrm{S}$ (respectively: $120 \mathrm{~N}$, $100 \mathrm{P}_{2} \mathrm{O}_{5}, 120 \mathrm{~K}_{2} \mathrm{O}, 40 \mathrm{MgO}, 60 \mathrm{Ca}, 30 \mathrm{SO}_{2} \mathrm{~kg} \mathrm{ha}^{-1}$ ); $\mathrm{MS}=\mathrm{PS}+155 \mathrm{t} \mathrm{DW}$ of $\mathrm{MS} \mathrm{ha}^{-1} ; \mathrm{BD}=\mathrm{PS}+5.1 \mathrm{t} \mathrm{DW}$ of $\mathrm{BD} \mathrm{ha}{ }^{-1} ; \mathrm{MS}+\mathrm{BD}=\mathrm{PS}+155 \mathrm{t} \mathrm{DW}$ of $\mathrm{MS} \mathrm{ha}^{-1}+5.1 \mathrm{t}$ DW of BD ha ${ }^{-1} ;{ }^{a, b, c} \ldots$ - data marked with the same letters do not differ significantly; DW = dry weight

The basic parameter regulating the soil's ability to buffer is its $\mathrm{pH}$, which is correlated to the redox potential pe and the content of $\mathrm{Ca}$ and $\mathrm{Mn}$ in the soil [37]. Solubility of heavy metals can become problematic under conditions of acidic soils and low $\mathrm{Ca}$ and $\mathrm{Mg}$ content. Under such conditions, the heavy metal retention mechanisms in which the exchange of heavy metals with $\mathrm{Ca}$ and $\mathrm{Mg}$ occurs, primarily surface precipitation, are disturbed [38].

An increase in the accumulation of heavy metals is further linked to the mechanisms of plant physiology facilitating the uptake of elements under their deficiency in the soil (P and Mg in particular). The deficiency of macroand micronutrients in the soil results in the exudation of carboxylates and phenols by plant roots. These compounds increase the biological assimilation of nutrient elements, unfortunately increasing the bioavailability of heavy metals [37-38]. Another mechanism of bioavailability changes of heavy metals is the activity of soil microorganisms related to the soil parameters ( $\mathrm{pH}$, organic matter content, etc.) [39, 41]. Moreover, the use of suitable combinations of rhizobacteria strains (Bacteroidetes bacterium, Pseudomonas fluorescens, and Variovorax sp.) can control the metal uptake of rapeseed, 
selectively increasing either metal extraction or metal stabilization in the rhizosphere [42].

In studies by Gisbert et al. [43], concentrations of $\mathrm{Pb}$ and $\mathrm{Zn}$ in Brassica oleracea were related more closely to total soil concentration than to DTPA-extractable concentrations of these elements. In addition, their control soil $(\mathrm{pH}=6.51)$ had a higher bioaccumulation index of $\mathrm{Cu}$ and $\mathrm{Mn}$ than contaminated soil $(\mathrm{pH}=7.34)$. As a result, $B$. oleracea growing on soil with a lower concentration of $\mathrm{Cu}$ and $\mathrm{Mn}(\mathrm{pH}=6.51)$ contained more $\mathrm{Cu}$ and $\mathrm{Mn}$ than $B$. oleracea growing on soil with a higher concentration of $\mathrm{Cu}$ and $\mathrm{Mn}$, but higher $\mathrm{pH}$ (7.34).

Particularly noteworthy is the Al content that was high in OSR seeds (from 70.85- MS to $104.38 \mathrm{mg} \mathrm{kg}^{-1}$ D.W. - C) and in soil (from 4172.95 - BD to $5184.63 \mathrm{mg} \mathrm{kg}^{-1}$ D.W. - MS+BD) (Tables S1 and S2). In 2007, Joint FAO/WHO Expert Committee on Food Additives (JECFA) developed a Provisional Tolerable Weekly Intake (PTWI) for Al from all sources of $1 \mathrm{mg} \mathrm{kg}{ }^{-1}$ of body weight (FAO/WHO, 2007). However, there remain uncertainties as to the extent of aluminium absorption from drinking water, which depends on a number of parameters, such as the Al salt administered, $\mathrm{pH}$ (for Al speciation and solubility), bioavailability, and dietary factors. Therefore, the committee applied an uncertainty factor of 100 to the lower end of this range of LOELs $\left(50 \mathrm{mg} \mathrm{kg}^{-1}\right.$ b.w. per day expressed as $\mathrm{Al}$ ) to allow for inter- and intraspecies differences. In the natural environment, $\mathrm{Al}$ can be found mainly in the form of sparingly soluble silicates and aluminosilicates that are not harmful to humans. Some forms of aluminum in the right amount may be necessary for the proper functioning of living organisms. An increase in the most toxic form of aluminum $\left(\left[\mathrm{Al}\left(\mathrm{H}_{2} \mathrm{O}\right)_{6}\right]^{+3}\right.$ - in simplification: $\mathrm{Al}^{3+}$ ) in the soil is associated with an increase in soil acidification. Its harmfulness is the chemical sorption of phosphates and $\mathrm{Al}^{3+}$ antagonism in relation to $\mathrm{Ca}^{2+}$ and $\mathrm{Mg}^{2+}$ [44].

\section{Conclusions}

The results obtained after three years of organic waste (biogas digestate) and mineral waste (carboniferous mudstones and clay rocks from coal mine) use as fertilization for rapeseed suggest that the wastes evaluated can be an interesting alternative for conventional fertilization. The biochemical quality parameters, nutritional value, and yield of oilseed rape were similar to conventional fertilization. In some cases (especially coaplication of wastes) these parameters were better than in conventional fertilization and in no fertilization. The content of heavy metals in rapeseeds as well as in the soil did not exceed the international permissible limits of heavy metals concentrations in soil and plants. The exception was $\mathrm{Al}, \mathrm{Fe}, \mathrm{Cr}$, and $\mathrm{Cd}$ in seeds, whose concentration was noticed above the restrictive limit set by WHO. However, this had no connection with the use of wastes to fertilization, because wastes and conventional fertilization decreased the content of these elements in seeds compared to control (without fertilization). Nevertheless, to recognize tested wastes as a full-value fertilizer, studies in this area should be continued.

\section{Acknowledgements}

The research was conducted within the statutory activity of the Department of Agricultural Ecology, University of Life Sciences in Lublin. We acknowledge technical support from the Department of Environmental Chemistry of the University of Maria Skłodowska-Curie in Lublin.

\section{Conflict of Interest}

The authors declare no conflict of interest.

\section{References}

1. JASKULSKI D., JASKULSKA I. Possibility of using the waste from the production process of polyvinyl chloride to product generating for plant fertilization. Pol. J. Environ. Stud. 20 (2), 351, 2011.

2. BOWSZYS T., SĄDEJ W., WIERZBOWSKA J. Use of agricultural and communal waste products in fertilization of oilseed rape grown for biofuel. TEKA EKA Kom. Mot. Energ. Roln., 7 (A), 43, 2007.

3. BENI C., SERVADIO P., MARCONI S., NERI U., AROMOLO R., GIAMPIETRO D. Anaerobic Digestate Administration: Effect on Soil Physical and Mechanical Behavior. Commun. Soil. Sci. Plant., 43 (5), 821, 2012.

4. CHEN R., BLAGODATSKAYA E., SENBAYRAM M., BLAGODATSKY S., MYACHINA O., DITTERT K., KUZYAKOVE Y. Decomposition of biogas residues in soil and their effects on microbial growth kinetics and enzyme activities. Biomass. Bioenergy, 45, 221, 2012.

5. LOPEDOTA O., LEOGRANDE R., FIORE A., DEBIASE G., MONTEMURRO F. Yield and Soil Responses of Melon Grown with Different Organic Fertilizers. J. Plant Nutr. 36 (3), 415, 2013.

6. KÖSTER J.R., CÁRDENAS L., SENBAYRAM M., BOL R., WELL R., BUTLER M., MÜHLING K.H., DITTERT $\mathrm{K}$. Rapid shift from denitrification to nitrification in soil after biogas residue application as indicated by nitrous oxide isotopomers. Soil. Biol. Biochem. 43 (8), 1671, 2011.

7. ALBURQUERQUE J.A., DE LA FUENTE C., CAMPOY M.M., CARRASCOA L., NÁJERAB I., BAIXAULIB C., CARAVACAA F., ROLDÁNA A., CEGARRAA J., BERNAL M.P. Agricultural use of digestate for horticultural crop production and improvement of soil properties. Eur. J. Agron., 43, 119, 2012.

8. DEMIREL B., GÖL N.P., ONAY T.T. Evaluation of heavy metal content in digestate from batch anaerobic codigestion of sunflower hulls and poultry manure. J. Mater. Cycles Waste 15 (2), 246, 2013.

9. RÓŻYŁO K., GAWLIK-DZIKI U., ŚWIECA M., RÓŻYŁO R., PAŁYS E. Winter wheat fertilized with biogas residue 
and mining waste - yielding and the quality of grain. J. Sci. Food Agric. 96 (10), 3454, 2015a.

10. RÓŻYŁO K., OLESZCZUK P., JOŚKO I., KRASKA P., KWIECIŃSKA-POPPE E., ANDRUSZCZAK S. An ecotoxicological evaluation of soil fertilized with biogas residues or mining waste. Environ. Sci. Pollut. Res. 22 (10), $7833, \mathbf{2 0 1 5 b}$

11. KOUTSOPOULOU E., PAPOULIS D., TSOLISKATAGAS P., KORNAROS M. Clay minerals used in sanitary landfills for the retention of organic and inorganic pollutants. Appl. Clay Sci. 49 (4), 372, 2010.

12. JABŁOŃSKA B. Sorption of phenol on rock components occurring in mine drainage water sediments. Int. J. Miner. Process. 104-105, 71, 2012.

13. ZHELJAZKOV V.D., VICK B., EBELHAR W., BUEHRING N., ASTATKIE T. Effect of $\mathrm{N}$ on yield and chemical profile of winter canola in Mississippi. J. Oleo. Sci. 62 (7), 453, 2013.

14. WAHID M.A., CHEEMA M.A., SALEEM M.F., NADEEM M., SATTAR A., ZAMAN M. Canola growth and phosphorus amendments. I. yield and quality response of canola to different phosphorus amendments. Pak. J. Agr. Sci. 51 (4), 847, 2014.

15. ALLAH M.M.-S.A., ELDIN M.M., SELIM S.M. Effect of nitrogen and sulfur on yield, yield components, some chemical composition and nutritional quality of canola plant grown in saline soil condition. Res. J. Pharm., Biol. Chem. Sci., 6 (3), 1055, 2015.

16. BEGUM F., HOSSAIN F., ISLAM M.M., MONDAL M.R.I. Effect of sulphur on biochemical parameters of rapeseed (Brassica campestris L.) in grey terrace soil. Arch. Agron. Soil. Sci., 62 (2), 261, 2016.

17. ZHAO J., LAWRENCE C.D., VERPOORTE R. Elicitor signal transduction leading to production of plant secondary metabolites. Biotechnol. Adv. 23 (4), 283, 2005.

18. GAWLIK-DZIKI U., ŚWIECA M., DZIKI D., SUGIER D. Improvement of nutraceutical value of broccoli sprouts by natural elicitors. Acta Sci. Pol-Hortorum Cultus 12 (1), 129, 2013.

19. OLESZCZUK P., MALARA A., JOŚKO I., LESIUK A. The phytotoxicity changes of sewage sludge amended soils. Water Air Soil Poll. 223 (8), 4937, 2012.

20. BURDGE G.C., CALDER P.C. Conversion of $\alpha$-linolenic acid to longer-chain polyunsaturated fatty acids in human adults. Reprod. Nutr. Dev., 45 (5), 581, 2005.

21. BRENNA J.T., SALEM J.N., SINCLAIR A.J., CUNNANE S.C. $\alpha$-Linolenic acid supplementation and conversion to n-3 long-chain polyunsaturated fatty acids in humans. Prostaglandins Leukot. Essent. Fatty Acids, 80 (2-3), 85, 2009.

22. MIŠURCOVÁ L., AMBROŽOVÁ J., SAMEK D. Seaweed lipids as nutraceuticals. Adv. Food Nutr. Res. 64, 339, 2011.

23. ORSAVOVA J., MISURCOVA L., AMBROZOVA J.V., VICHA R., MLCEK J. Fatty Acids Composition of Vegetable Oils and Its Contribution to Dietary Energy Intake and Dependence of Cardiovascular Mortality on Dietary Intake of Fatty Acids. Int. J. Mol. Sci. 16 (6), 12871, 2015.

24. HUANG C., FRETER C. Lipid metabolism, apoptosis and cancer therapy. Int. J. Mol. Sci. 16 (1), 924, 2015.

25. SIMMONS G.E., PRUITT W.M., PRUITT K. Diverse roles of SIRT1 in cancer biology and lipid metabolism. Int. J. Mol. Sci. 16 (1), 950, 2015.

26. MALHI S.S., VERA C.L., BRANDT S.A. Relative effectiveness of organic and inorganic nutrient sources in improving yield, seed quality and nutrient uptake of canola. Agricultural Sci. 4 (12A), 1, 2013.

27. MA B-L., BISWAS D.K., HERATH A.W., WHALEN J.K., RUAN S.Q., CALDWELL C., EARL H., VANASSE A., SCOTT P., SMITH D.L. Growth, yield, and yield components of canola as affected by nitrogen, sulfur, and boron application. J. Plant Nutr. Soil Sci. 178 (4), 658, 2015.

28. AHMAD G., JAN A., ARIF M., JAN M.T., KHATTAK R.A. Influence of nitrogen and sulfur fertilization on quality of canola (Brassica napus L.) under rainfed conditions. J. Zhejiang Univ-Sc. B., 8 (10), 731, 2007.

29. WANG Y., LI J., GAO X., LI X., REN T., CONG R., LU J. Winter Oilseed Rape Productivity and Nutritional Quality Responses to Zinc Fertilization. Agron. J. 106 (4), 1349, 2014.

30. CORDAIN L., EATON S.B., SEBASTIAN A., MANN N., LINDEBERG S., WATKINS B.A., O'KEEFE J.H., BRAND-MILLER J. Origins and evolution of the Western diet: Health implications for the 21st century. Am. J. Clin. Nutr., 81, 341, 2005.

31. ONEMLI F. Fatty Acid Content of Seed at Different Development Stages in Canola on Different Soil Types with Low Organic Matter. Plant Prod. Sci. 17 (3), 253, 2014.

32. BAUER B., KOSTIK V., GJORGESKA B. Fatty acid composition of seed oil obtained from different canola varieties. Farmaceutski glasnik, 71 (1), 1, 2015.

33. MEKKI B.B. Yield and Quality Traits of Some Canola Varieties Grown in Newly Reclaimed Sandy Soils in Egypt. World App. Sci. J. 25 (2), 258, 2013.

34. KHODDAMI A., MAN Y.B.C., ROBERTS T.H. Physicochemical properties and fatty acid profile of seed oils from pomegranate (Punica granatum L.) extracted by cold pressing. Eur. J. Lipid Sci. Tech. 116 (5), 553, 2014.

35. SALAMA Z.A., YOUSSEF M.A., TAIE H.A., EL-BAZ F.K. Increasing Omega 6, Omega 9 Fatty Acids and Oil Contents in Black Sesame Seed by Biofertilizer and Micronutrients Application. Int. J. Pharm. Sci. Rev. Res. 31 (1), 256, 2015

36. SWATI A., HAIT S. Fate and bioavailability of heavy metals during vermicomposting of various organic wastes - A review. Process Saf. Environ. Prot. 109, 30, 2017.

37. ESHEL G., LIN C.H., BANINC A. Novel approach for quantitatively estimating element retention and material balances in soil profiles of recharge basins used for wastewater reclamation. Sci. Total Environ. 502, 517 , 2015.

38. MELO L.C.A., PUGA A.P., COSCIONE A.R., BEESLEY L., ABREU C.A., CAMARGO O.A. Sorption and desorption of cadmium and zinc in two tropical soils amended with sugarcane-straw-derived biochar. J. Soils. Sediments. 16 (1), 226, 2016.

39. CLEMENS S., PALMGREN M.G., KRÄMER U. A long way ahead: understanding and engineering plant metal accumulation. Trends Plant. Sci., 7 (7), 309, 2002.

40. GHERARDI M., RENGEL $Z$. The effect of manganese supply on exudation of carboxylates by roots of lucerne (Medicago sativa). Plant Soil 260 (1-2), 271, 2004

41. JIANG C.Y., SHENG X.F., QIAN M., WANG Q.Y. Isolation and characterization of a heavy metal resistant Burkholderia sp. from heavy metal-contaminated paddy field soil and its potential in promoting plant growth and heavy metal accumulation in metal polluted soil. Chemosphere 72 (2), 157, 2008. 
42. DĄBROWSKA G., HRYNKIEWICZ K., TREJGELL A., BAUM C. The effect of plant growth-promoting rhizobacteria on the phytoextraction of $\mathrm{Cd}$ and $\mathrm{Zn}$ by Brassica Napus L. Int. J. Phytoremediat. 19 (7), 597, 2017.

43. GISBERT C., CLEMENTE 1R., NAVARRO-AVINO J., BAIXAULI C., GINER A., SERRANO R., WALKER D.J., BERNAL M.P. Tolerance and accumulation of heavy metals by Brassicaceae species grown in contaminated soils from Mediterranean regions of Spain. Environ. Exp. Bot. 56 (1), 19, 2006.

44. ZUZIAK J., JAKUBOWSKA M. Aluminum in the environment and its influence on living organisms. Analit. 2, 110, 2016. 
